DOI: https://doi.org/10.31933/dijemss.v2i3

Received: $23^{\text {rd }}$ December 2020, Revised: $15^{\text {th }}$ January 2021, Publish: $2^{\text {nd }}$ March 2021

\begin{tabular}{|c|c|c|}
\hline PUNASTSI & $\begin{array}{l}\text { DIJEMSS } \\
\text { DINASTI INTERNATIONAL JOURNAL } \\
\text { OF EDUCATION MANAGEMENT AND } \\
\text { SOCIAL SCIENCE }\end{array}$ & $\begin{array}{r}\text { https://dinastipub.org/DIJEMSS } \\
\text { editor@dinastipub.org } \\
08117401455 \Omega\end{array}$ \\
\hline
\end{tabular}

\title{
THE ANALYSIS RELATED TO THE FACTORS WHICH AFFECT THE POVERTY LEVELS OF DISTRICTS/CITIES IN JAMBI PROVINCE DURING 2014-2018
}

\author{
Muhammad Safri ${ }^{1}$ \\ ${ }^{1)}$ Lecturer in Economy \& Business Faculty, Universitas Jambi, Indonesia, m_syafri@ unja.ac.id
}

Corresponding Author: Muhammad Safri

\begin{abstract}
Poverty is an issue faced by nearly all developing countries or third world countries, including Indonesia. Jambi Province is one of the provinces in Indonesia which cannot be separated from poverty. Several efforts have been made by district/city governments in Jambi Province to reduce its levels by implementing the poverty alleviation programs issued by the central government. These implementation of poverty alleviation programs carried out by the district/cities governments in Jambi Province showed there has been reduction over these issues in districts/cities in Jambi Province, but only in a small percentage. The economic growth which tends to increase every year in the districts/cities of Jambi Province has not been followed by a significant reduction in poverty levels. This condition required the districts/cities governments to advance a more comprehensive strategy in carrying out poverty alleviation that takes place in districts/cities of Jambi Province. Therefore, this research aimed to investigate those factors which affected the poverty level in districts/cities of Jambi Province. Data used in this research included panel data, namely the 2013-2018 time series data and the cross section data of 11 districts/cities through the Fixed Effect Model approach. These results showed that economic growth and Human Development Index had a significant negative affect on poverty levels.
\end{abstract}

Keywords: Poverty rate, economic growth, human development index, education level, unemployment rate.

\section{INTRODUCTION}

Poverty will continue to increase and it tends to increase alongside thepopulation growth which is difficult to control, especially in developing countries. Striking levels of extreme poverty have occurred so far in developing countries (Todaro and Smith 2011:250). Poverty issues which appears in developing countries are the main issues that should be addressed by the government. The high number of poor people in developing 
countries has resulted in numerous impacts, both of social and economic. Efforts to cut the poverty are not an easy matter, especially in developing countries. Various poverty reduction programs were implemented to diminish the level of poverty occurred.

This poverty which occurs in a country requires a strategy and steps for handling and systematic, integrated and comprehensive methods. Comprehensive poverty reduction efforts demand contribution and participation from various parties and stakeholders. The central government, local governments, businesses and community are parties who have the same role on this poverty reduction program (TNP2K, 2015).

The poverty rate of Jambi Province in 2013 was $8.41 \%$ and decreased in 2018 to $7.92 \%$. But this declined still not based on the target set by Jambi Province RPJMD which has targeted that in 2018 the poverty rate of Jambi Province should be fall to $6.84 \%$.

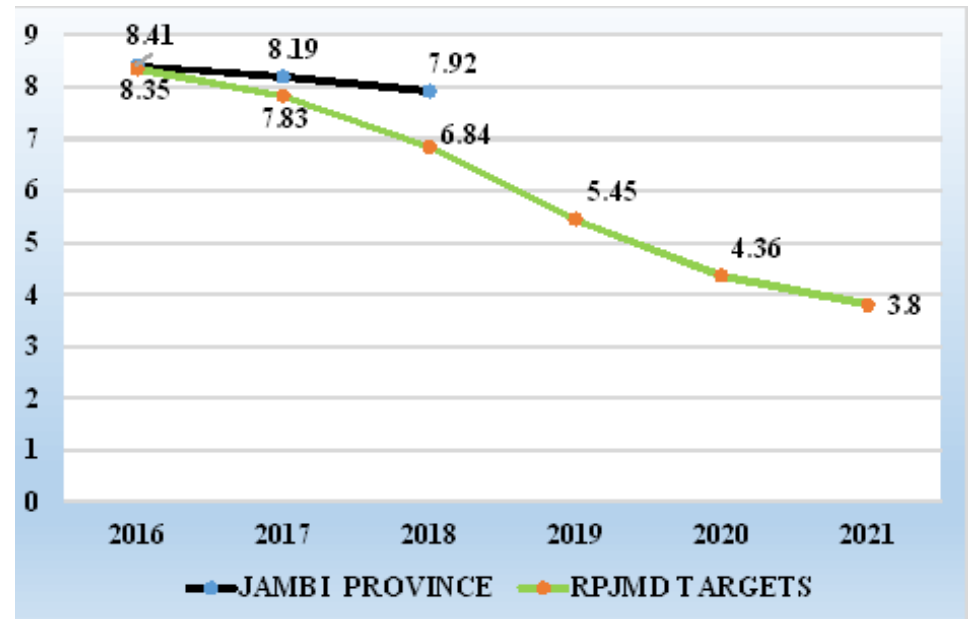

Figure 1. The Comparison between the Achievement of Poverty Reduction with the RPJMD Jambi Province's Targets During 2016-2018

These poverty issues are the main obstacle of the development stage in Indonesia. The development carried out by the Indonesian government so far has indeed resulted in a relatively high level of economic growth, but the fact these economic growth results have not been fully enjoyed by all Indonesians probably by some. On the average, the poor in the developing countries would enjoy less the benefits of this economic growth, which tends to increase. And this condition would make it difficult for the poor to escape from the trap of poverty itself.

Efforts to reduce poverty levels occurred in Indonesia are one of the main purposes of various public policies issued and carried out by each region and nationally. One aspect from government policy which is important in alleviating poverty is fiscal policy or budget for poverty reduction. The government budget that is pro to the poor is an important instrument for policy making to overcome this poverty problems. (Maipita 2014:178).

Zakaria's research (2014) on the spatial analysis of poverty and factors which affected it in districts/cities of Central Java Province used spatial analysis tools (gis and spatial autocorrelation), regional typology and panel regression (fixed effect model with 
GLS method and white period standard error and covariance). The results showed if the districts with higher poverty levels tend to grouping in the southern part of western central Java (Cilacap Regency and its surroundings), while Demak regency is a spatial outlier. The indicators of monetary poverty, health and education have a negative and significant affect on poverty levels, thus indicated that the development policies in Central Java are side on the poor growth and pro poor budgeting.

Putri's research (2013) on the analysis of factors which affect the level of poverty in Bali Province. This research was conducted in all districts/cities of Bali Province through secondary data. The data collection method used non-behavioral observation techniques. The analysis technique used was multiple linear regression. Based on these analysis, it was found that economic growth, minimum wages, education level and unemployment rate simultaneously affected poverty levels. Economic growth, minimum wages and education level partially have a negative and significant impact on it, while the unemployment rate partially has a positive but insignificant impact towards the poverty level.

Based on the background which has been mentioned above, the author wants to organize research to explore the impact of economic growth, human development index, education level and unemployment rate on poverty levels in district/cities of Jambi Province over the last six years with the title of "The Analysis related to the factors which affected the Poverty Levels of districts/cities in Jambi Province during 2014-2018". Based on this description, it would find out whether the economic growth, human development index, education level, and unemployment rate which has impact on the poverty level of districts/cities in Jambi Province during the period of 2013-2018?. Because the main purpose of this research was to determined the impact of economic growth, human development index, education level and unemployment rate on districts/cities poverty levels in Jambi Province during the period 2013-2018.

\section{LITERATURE REVIEW The Poverty}

The World Bank (BPS, 2015) defines the poverty as "lack of shelter." Poverty is being sick and not being able to see the doctor. Poverty is being able to go to school and not knowing how to read. Poverty is not having a job and fear of the future, living one day at a time. Poverty is losing a child to illness brought by unclean water. Poverty is powerlessness, lack of representation and freedom ".Poverty is related to homelessness, illness and being unable to go to the doctor, not being able to go to school but unable to read and write. Poverty is if you don't have a job so you are afraid to look up the future, you don't have access to clean water sources. Poverty is paralyzed, lack of representation and freedom.

Spicker in Maipita (2014:60) argues if the causes of poverty could be divided into four chapters, which is:

1) Individual explanation, this chapter sargues that poverty tends to be caused by the characteristics of the poor themselves. The characteristics referred to such as being lazy and not serious in everything, including work.

2) Familial explanation, this chapter said if the poverty is caused further by heredity. 
3) Subcultural explanation, according to this chapter opinion, the poverty could be caused by culture, habits, customs or due to the characteristics of environmental behavior.

4) Structural explnations, this chapter considered if the poverty arises as a result of imbalance, differences in status made by customs, policies and other regulations would arise to differences in the right of work, school and others, it causing the poverty among those with low status and limited rights.

\section{Economic Growth}

In the development stage carried out by each country, both developing and advanced countries, certainly, special indicators are needed to observed the performance of the development itself, such as one indicator which is often used by every country to measure its economic performance is the rate of economic growth. In simple terms, economic growth could be interpreted as an increase in the real national income of a country.

Economic growth is an advance in the long-term capacity of the country itself to provide various economic goods to its population which is determined by the progress or adjustments of technological, institutional (institutional) and ideological to those various demands from the existing circumstances Kuznets (Todaro, 2011).

\section{Human Development Index}

Along with the times, the needs of everyone will increase, both basic needs and secondary needs. At this recent point, the basic needs of a person are not only in the form of clothing, food and shelter, but at this time up to the level of education, health, and a decent life is the basic need of every population that should be granted. Not every person could meet the needs of education, health and a decent life, due to the limitations that they have, which is income. The role of the government is needed to fill up the development of the basic needs of society in the form of education, health and a decent life. The government through its programs needs to carry out useful programs to fill this requirement which are deemed very important. The current government has also determined if education and health are important aspects of the development agenda.

Reminding about the importance of education, health and a decent life for the community in development, a specifically measure is needed to find out the level of improvement on these three aspects of community needs. The measuring instrument that has been used so far is the Human Development Index (IPM).According to BPS (2015) the Human Development Index (HDI) measures the achievement of human development based on a number of basic components of quality of life. As a measure of quality of life, HDI is built based on three-dimensional methods. These dimensions were include long life and health also knowledge and a decent life.

\section{Unemployment}

Unemployment is someone who is already classified in the labor force who is actively looking for work at a certain wage level, but cannot get the job as their expected. Unemployment is usually divided into 3 types based on the circumstances which cause it, namely frictional, structural and conjunctive unemployment, while the types of unemployment are characterized by these following (Sadono Sukirno 2000) such as: a) 
Open Unemployment which occurs as a result of the growth in the number of workers that is not balanced with the jobs availability on market so that many workers do not get jobs. According to the Central Statistics Agency (BPS), open unemployment is a population who has entered the workforce but does not have a job and still looking for work, preparing a business and already has a job but not started yet. b) Hidden unemployment a condition in which a type of economic activity is carried out by a workforce whose number is more than necessary. c) Unemployment Seasonal that occurs at certain times of the year. This phenomenon often occurs in the agricultural sector where farmers will be idle while waiting for the planting period and when the interval between planting season and harvest season. d) Underemployed Half Unemployed are workers who do not work optimally due to the absence of employment or jobs or workers who work less than 35 hours a week. Based on the Central Statistics Agency (BPS), in Indonesia normal working hours are 35 hours a week. Unemployment could affect poverty in many ways. If the household has a liquidity limit (which means that current consumption is strongly influenced by current income) then unemployment will directly affect poverty both as measured in terms of income (income poverty rate) and poverty as measured in terms of consumption (consumption poverty rate).If the household does not face liquidity constraints (meaning that current consumption is less affected by current income) then an increase in unemployment will lead to an increase in poverty for the long run, but less in the short term.

\section{The Linkage between Economic Growth and Poverty}

Based on the trickle down effect theory, the economic growth that occurs will drop from top to bottom, or in the sense that the level of increase in real income will flow from the rich to the poor. Economic growth will be more beneficial, if this growth could be enjoyed by each community group. In developed countries, the level of economic growth is more evenly distributed, so that the poverty rate is less compared to developing countries.

How this progress could reduce the poverty, it could simply be shown by Figure 1, economic growth will increase the demand for output, increase the production capacity of workers and open new jobs. All of this will lead to an increase in workers' income. An Increased income will have an impact on increased spending, such as spending for education, health, and skills development (poverty reduction). These conditions would create the possibility of further increases in productivity and higher rates of economic growth (Maipita 2014:64). 


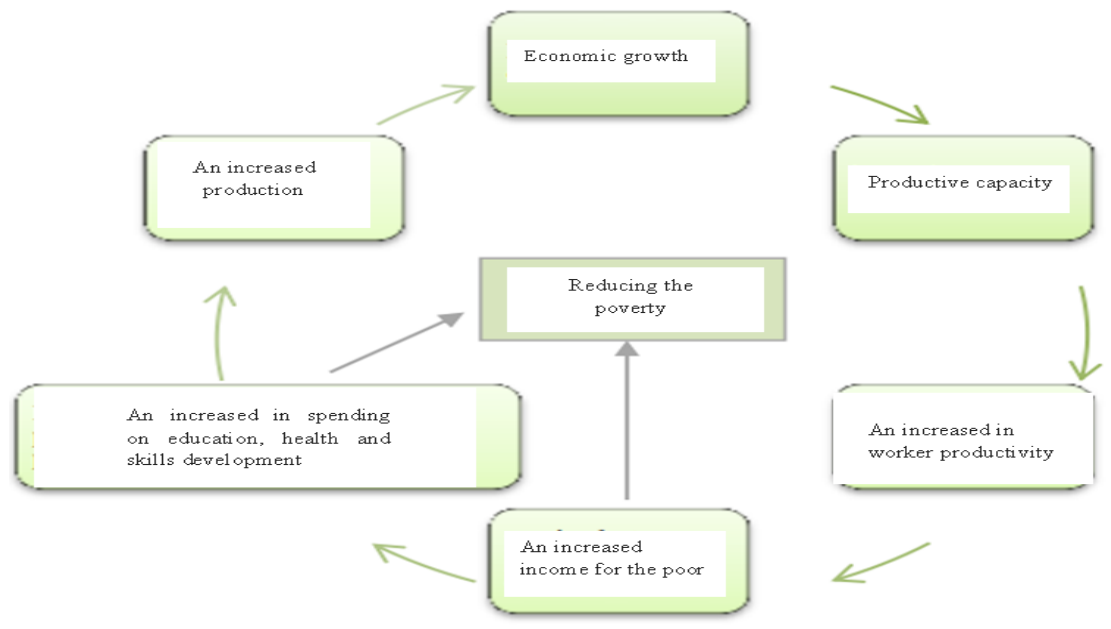

Figure 2. The Linkage between Economic Growth and Poverty The Linkage between Human Development Index and Poverty

The Human Development Index is a tool used to measure the level of population welfare. The welfare of the population would reflect the population that has been able to fulfill their daily needs, then with the high welfare, the population could be categorized as a non-poor population. The welfare of the population could be evaluated by several aspects, such as aspects of education, health and income of each individual. Where each of these aspects has been included in the human development index figures.

According to Mahmudi in Widodo (2011), in this vicious cycle of poverty there are three main axes that cause a person to become poor, namely 1) low level of health, 2) low income and 3) low level of education. The low level of health is one of which triggers poverty because a low level of public health will cause a low level of productivity. Low productivity levels further lead to low income and low income leads to poverty. Poverty in turn causes a person to be unable to access quality education and pay for health care and protection.

\section{The Linkage between Unemployment Rate and Poverty Level}

Arsyad (2010) stated that there is a very close relations between high levels of unemployment and poverty.For most people, those who do not have permanent or only part-time jobs are always among the very poor groups of people.The literature review represents the theoretical core of an article.In this section, we will discuss the objectives of the literature review.We will also consider that how someone should search for the appropriate literature on which to base the literature review and how this information should be managed.

\section{Hypothesis}

1) It is suspected if the economic growth variable has a negative impact on the poverty level of districts/cities in Jambi Province

2) It is suspected if the Human Development Index variable has a negative impact on the poverty level of districts/cities in Jambi Province.

3) It is suspected if the education level variable has a negative impact on the poverty level of districts/cities in Jambi Province 
4) It is suspected if the level of unemployment variable has a negative impact on the poverty level of districts/cities in Jambi Province.

\section{RESEARCH METHODS}

This research was included in quantitative research. According to Sugiyono (2012), quantitative research methods could be defined as research methods based on the philosophy of positivism that used to research on certain populations or samples. Collecting data through research instruments, both quantitative/statistical data analysis with the aim of examining the predetermined hypothesis (Sugiyono, 2012). The time used in this research was from 2013 to 2018, while the research place was Jambi Province.

The dependent variable in this research was the level of poverty in districts/cities of Jambi Province. Meanwhile, the independent variables in this research were economic growth, human development index, education level and unemployment rate. The analysis method used was an analysis technique, namely panel data regression with a fixed effect approach through the EViews 11.0 program. Particularly this research has purpose on the impact of economic growth, Human Development Index (HDI), Education Level, and Unemployment Rate on poverty levels in each district/ city of Jambi Province. The data used are time series data for the period of 2013 to 2018 and cross section data was 11 districts/cities in Jambi Province. The results from these combination of time series and cross section data resulted in 66 observations. The panel data regression model equation function could be served as follows:

$$
\begin{array}{ll}
\mathrm{TK}_{\mathrm{it}}=\beta_{0}+\beta_{1} \mathrm{PE}_{\mathrm{it}}+\beta_{2} \mathrm{IPM}_{\mathrm{it}}+\beta_{3} \mathrm{TPT}_{\mathrm{it}}+\beta_{4} \mathrm{TP}_{\mathrm{it}}+\mu_{\mathrm{it}} \ldots \ldots \ldots \ldots \ldots \ldots \ldots \ldots \ldots \ldots \ldots \ldots \ldots \ldots \\
\mathrm{TK} & =\text { Poverty level of each district } / \text { city in Jambi Province } \\
\mathrm{PE} & =\text { Economic growth of each district / city in Jambi Province } \\
\mathrm{IPM} & =\text { Human development index of each district / city in Jambi Province } \\
\mathrm{TPT} & =\text { Open Unemployment Rate of each district / city in Jambi Province } \\
\mathrm{TP} & =\text { Education level of each district / city in Jambi Province } \\
\beta_{0} & =\text { Intercept } \\
\beta_{1}-\beta_{5} & =\text { Independent variable of regression coefficient } \\
\mu_{\mathrm{it}} & =\text { Error Term (Standard Error) } \\
\mathrm{i} & =\text { Cross Section } \\
\mathrm{t} & =\text { Time Series }
\end{array}
$$

\section{RESULT AND DISCUSSION Analysis Results}

The analysis was carried out to answer the problems and research the hypothesis regarding the factors which affecting the poverty level of districts/cities in Jambi Province during the period of 2014-2018. To view the impact of economic growth variables, human development index, unemployment rate and the education level of districts/cities in Jambi Province in 2014-2018 through the Fixed Effect Model (FEM) method. The results of this time series data which processed through Eviews 11 then obtained this regression efficiency values for each variable in this research as shown in the table below. 
Table 1. Regression Results

\begin{tabular}{|c|c|c|c|c|}
\hline Variable & Coefficient & Std. Error & t-Statistic & Prob. \\
\hline $\mathrm{C}$ & 34.48357 & 1.087136 & 31.71965 & 0.0000 \\
\hline IPM & -0.166290 & 0.018434 & -9.021049 & 0.0000 \\
\hline $\mathrm{PE}$ & -0.691030 & 0.033469 & -20.64691 & 0.0000 \\
\hline TPT & -0.045726 & 0.031402 & -1.456127 & 0.1455 \\
\hline $\mathrm{TP}$ & -0.129450 & 0.010127 & -12.78256 & 0.0000 \\
\hline \multicolumn{5}{|c|}{ Cross-section fixed (dummy variables) } \\
\hline Root MSE & 2.309342 & $\mathrm{R}$-squared & & 0.393177 \\
\hline Mean dependent var & 8.247091 & Adjusted R-square & & 0.381311 \\
\hline S.D. dependent var & 2.965030 & S.E. of regression & & 2.332198 \\
\hline A kaike info criterion & 4.550811 & Sum squared resid & & 16132.51 \\
\hline Schwarz criterion & 4.668122 & Log likelihood & & -6824.101 \\
\hline Hannan-Quinn criter. & 4.592989 & F-statistic & & 33.13365 \\
\hline Durbin-Watson stat & 0.747383 & Prob(F-statistic) & & 0.000000 \\
\hline
\end{tabular}

Source: Eviews 11, processed data

The research outcomes resulted from the regression equation that could explain the impact of each independent variable on the dependent variable. According to this research result, the regression equation obtained could be quoted as follows:

The level of Poverty = $34.48357-0.166290(\mathrm{HDI})-0.691030(\mathrm{PE})-0.045726(\mathrm{TPT})$

$$
0.129450 \quad(\mathrm{TP}) \quad+
$$

The economic growth variable in this research shows a negative coefficient number and significantly influences the economic growth variable, human development index and education level, while the open unemployment rate variable has a negative but insignificant coefficient number.

Human Development Index variable has a negative and significant coefficient on the poverty level of districts / cities in Jambi Province. It is proven that if there is an increase in the human development index figure by $1 \%$, it will reduce the poverty level of districts/cities in Jambi Province by $0.166290 \%$ with a constant assumption of variables outside the Human Development Index.

The economic growth variable has a negative and significant coefficient on poverty of districts/cities in Jambi Province. It is proven that if there has an increase in economic growth of $1 \%$, it will reduce the poverty level of districts/cities in Jambi Province by $0.691030 \%$ with a constant assumption of variables outside of economic growth.

Open unemployment rate variable has a negative and insignificant coefficient on the poverty level of districts/cities in Jambi Province. It is proven that if there is an increase in unemployment by $1 \%$, it will reduce the poverty level of districts/cities in Jambi Province by $0.045726 \%$ with a constant assumption of variables outside of economic growth.

The education level variable has a negative and significant coefficient on poverty of districts/cities in Jambi Province. It is proven that if there is an increase in the level of education by $1 \%$, it will reduce the poverty level of districts/cities in Jambi Province by $0.129450 \%$ with a constant assumption of variables outside of economic growth. 


\section{Discussion}

\section{The Impact of Economic Growth on Poverty}

Based on the regression results, it is found that the coefficient of economic growth was positive and statistically significant on the poverty level of districts/cities in Jambi Province. This shows that with the increase in economic growth, the poverty rate in districts/cities in Jambi has also increased, and conversely. This result did not match with the trickle-down theory which stated if economic growth could reduce poverty, where a part of economic growth based on trickle down theory was from the rich to the poor.

According to the trickle down effect theory, the economic growth which occurs in an area will produce two possibilities. First, when economic growth restricts the difference between rich and poor regions, then it means a trickle down effect occurs. Second, when economic growth widens the difference between rich regions and poor regions, meaning the polarization process occurs.

The polarization process will occur when each sector that contributes to economic growth does not have strong correlations. The urban industrial sectors have progressed quite rapidly and succeeded in contributing a huge growth to the economic growth of a region. The agricultural sector, which supports the lives of rural communities, was experience relatively slow growth compared to other sectors. This has resulted on economic growth in that area will only be enjoyed by rich urban communities, whose economy is supported by the industrial sector.

Rural communities are financially supported by the agricultural sector with still many groups of poverty there. It causes the underdevelopment of the agricultural sector.

Based on the cumulative causation theory, the progress in advance regions will lead to conditions that will create greater obstacles for poor regions to progress and develop. These conditions which interrupt this improvement are known as backwash effects. According to Myrdal, there are three factors which cause the appearance of backwash effects, namely patterns of population movement (migration) from poor countries to advanced countries, patterns of capital flows that occur and better transportation networks in advanced countries.

\section{The Impact of the Human Development Index on Poverty}

Based on these regression results, it is found that the coefficient of the Human Development Index was negative and statistically significant on the poverty level of districts/cities in Jambi Province. It is proven by an increase in the Human Development Index, will decrease the poverty level of districts/cities in Jambi Province and conversely.

Poverty as a multidimensional issue, certainly will also look at the social aspects related to education and health problems. Thus, these two aspects (education and health) are one of the indicators of poverty. The better the quality of education and health, the lower the level of poverty in an area. One of the estimation tools used to identify the quality of education and health is the Human Development Index (HDI). HDI could measure the impact of regional development performance which has a very wide 
dimension, because it shows the quality of the population from an area in terms of life expectancy, intellectuality and a decent standard of living.

The Human Development Index consists of three constituents. First is Life Expectancy (AHH). AHH is an indicator which describes the level of health progress in an area. Second is the Literacy Rate $(\mathrm{AMH})$, which is an indicator of education in an area. Third is the average length of school of the population and also measures the quality of education in an area. The last one is real per capita expenditure, which is an economic index used to compare real prices between regions.

\section{The Impact of the Open Unemployment Rate on the Poverty Level}

The analysis results shows that the level of employment has a negative and significant affect on the level of poverty. Meaning if the higher the level of employment, the lower the poverty level of the community and it does conversely, if the lower the level of job opportunities avail, the higher the poverty level in the community at the regions.

This results viewed if the more job opportunities available to the community, the lower the level of poverty in an area. If employment opportunities are wide and absorb more workers, then poverty will decrease. Economic growth without additional employment opportunities will result in inequality which will create a condition for economic growth by increased poverty. This research is in line with some of the results from prior research and was consistent with the results of research by Yanthi (2011), Sunusi (2014) and Vera, et al. (2016) who obtained the results that the level of employment opportunity had a negative and significant affect on the poverty level.

\section{The Impact of Education Level on Poverty Levels}

Poverty levels could be caused by low economic growth and a very large population, as well as the level of public education. Education is a pioneer in the future development of a nation, because the quality of education could determine the quality of development. Through this education, a qualified human generation could be born and also with the rise of a quality human being can produce quality and maximum development. Therefore, every human being should always improve their quality through education which is carried out professionally so the goals for quality development will be achieved and work well (Amalia, 2017).

Based on the analysis results, it shows that education has an impact on the poverty level of districts/cities in Jambi Province. With low education, people would find it difficult to get a job, so they will have no income and eventually they will become poor. Likewise, with high education, people would find it easy to get a job with a decent wage that increases their welfare, therefore the poverty rate would decrease aswell. This result was in line with the results from previous research conducted by Aksentijevic (2006), Ukwuezze (2014), Zakharia (2006) and Capra (2009) which concluded that the level of education has an influence on the number of poor people. In addition, the results of this research were also in accordance with the theory put forward by Bloom (2006) which stated if education would be able to improve welfare and reduce poverty. As well as in accordance with the theory put forward by Arsyad (2010) which stated if education has an important role in reducing poverty in a country, either directly or indirectly. In addition to these two theories, the results of this research were also in according to the theory put 
forward by Dejanvry and Sadoulet in Kokila (2000) which stated if education reduces inequality and poverty directly, namely: by increasing productivity for the poor, improving their opportunities to obtain better paying jobs. Speaking about poverty, there are many reasons which could make a person poor, especially when it's viewed by perspective of life and attitudes towards work. There is someone or a group who has the view that's why by being rich in the world if you don't go to heaven in the future, what is important in the hereafter will go to heaven. Lifestyle will cause a person to be poor, such as a wasteful lifestyle. Lazy nature could lead to poverty, where a person is lazy to work so they cannot make ends meet. And apart from the factors of education, outlook on life and lifestyle as mentioned above, there are other factors which cause a person to become poor, including: low wages, lack of employment, rising prices of goods and etc.

\section{CONCLUSION AND SUGGESTION Conclusion}

Based on the data and analysis results, this research concluded that according to independent variables used, namely economic growth, human development index, education budget and health budget which has been proven affected the dependent variables, such as:

1) The level of economic growth had a negative and significant impact on the poverty level of districts/cities in Jambi Province. This could described if the economic growth increased, then the poverty rate of districts/cities in Jambi Province would decrease. It showed that the increased in economic growth during this research period played a role in reduced the poverty of districts/cities in Jambi Province.

2) The level of human development index (HDI) had a negative and significant impact on the poverty level of districts/cities in Jambi Province. This could described if the level of the human development index (HDI) increased, it would reduced the poverty level of districts/cities in Jambi Province.

3) The Open Unemployment Rate (TPT) had a negative and significant impact on the poverty level of districts/cities in Jambi Province. This could described if the open unemployment rate decreased, it would reduced the poverty level of districts/cities in Jambi Province.

4) The level of education (TP) of districts/cities in Jambi Province. This could described if the level of education (TP) increased, it would reduced the poverty level of districts/cities in Jambi Province.

\section{Suggestions}

Based on these research results, there are several suggestions that could be conveyed to reduced the poverty through the Government policy which need to do such as:

1) It needs a special effort by the government in order to carry out thedevelopment which is oriented on equal distribution of income and equal distribution from the results of economic growth. An high economic growth should be enjoyed by all people, especially to the poor, by involved them in economic activities so their welfare would get better, the community involvement probably as workers or economic actors by encouraged activities, therefore it would be an increased in community income.

2) Based on this research results, it was found if the human development index had a negative impact on reduced on the poverty level of districts/cities in Jambi Province. 
These results revealed that human development is an important aspect in poverty decreased, thus the government should be concerned about the human development index indicators which had an impact on human development for society, in this case specifically related to education and health. In an effort to increased the human development, government spending allocations should be aware to those human development efforts.

\section{REFERENCES}

Arsyad, L. (2010). Ekonomi Pembangunan. Yogyakarta. UPP STIM YKPN.

Badan Pusat Statistik. (2015). Analisis dan Penghitungan Tingkat Kemiskinan 2015. BPS. Jakarta.

Badan Pusat Statistik Provinsi Jambi. (2019). Tingkat kemiskinan dan Prosentase penduduk Miskin Tahun 2014-2018. BPS. Provinsi Jambi.

Maipita, I. (2014). Mengukur Kemiskinan dan Distribusi Pendapatan, Yogyakarta. UPP STIM YKPN.

Putri, I.A.S.M., \& Yuliarmi, N.N. (2013). Beberapa Faktor Yang Memengaruhi Tingkat Kemiskinan di Provinsi Bali. E-Jurnal EP Unud, 2(10), 441-448.

Simanjutak, T.H., \& Muklis, I. (2012). Dimensi Ekonomi Perpajakan dalamPembangunan Ekonomi. Jakarta. Rais Aksa Sukses.

Sugiyono. (2012). Metode Penelitian Kuantitatif Kualitatif dan R\&D. Alfabeta. Bandung.

Todaro, M.P., \& Smith, S.C. (2011). Pembangunan Ekonomi Jilid 1 Edisi 11. Penerbit: Erlangga. Jakarta.

Widodo, A., Waridin, \& Johanna, M.K. (2011). Analisis Pengaruh Pengeluaran Pemerintah Di Sektor Pendidikan Dan Kesehatan Terhadap Pengentasan Kemiskinan Melalui Peningkatan Pembangunan Manusia di Provinsi Jawa Tengah. Jurnal Dinamika Ekonomi Pembangunan, 1(1).

Yanthi, N. (2011).Pengaruh Pertumbuhan Ekonomi,Inflasi, dan Tingkat kesempatan Kerja Terhadap Tingkat Kemiskinan di Indonesia Tahun 1999 -2009. Skripsi. Fakultas Ekonomi Universitas Pembangunan Nasional "Veteran” Yogyakarta. 